\title{
Opóźnienia w funkcjonowaniu językowym jako wczesny symptom zaburzeń w rozwoju dziecka
}

\section{KEYWORDS}

linguistic development, disorders in the development of a child, delayed speech development, early diagnosis, therapeutic support

\begin{abstract}
Justyna Leszka, Opóźnienia w funkcjonowaniu językowym jako wczesny symptom zaburzeń w rozwoju dziecka [Linguistic Delays as an Early Symptom of Disorders in a Child's Development]. Kultura - Społeczeństwo - Edukacja nr 2(20) 2021, Poznań 2021, pp. 359-373, Adam Mickiewicz University Press. ISSN 2300-0422, ISSN (Online) 2719-2717. DOI 10.14746/kse.2021.20.23

Human linguistic development is constitutionally conditioned and is achieved through contact with adult language users. All children follow the same rules and stages in the development of speech. The knowledge of their course and consequences enables early recognition of deviations from the norm, which may be delayed speech development or a symptom of other, often serious developmental disorders. The analysis of the research results shows that the most common reason for parents' seeking diagnosis and therapeutic support is an incorrect linguistic functioning of the child. Diagnostic procedures often end with the diagnosis of other developmental disorders in which linguistic retardation was an early symptom. Therefore, it is legitimate to increase social knowledge and sensitivity of parents and specialists in monitoring the linguistic development of children under 3 years of age.
\end{abstract}

* ORCID: https://orcid.org/0000-0002-4202-7629. 


\section{Uwarunkowania rozwoju językowego człowieka}

Przedstawiając tezę, iż jednym z najważniejszych wyznaczników zaburzeń w rozwoju dziecka są nieprawidłowości w funkcjonowaniu językowym, należy zdefiniować, czym jest język, jak funkcjonuje w umyśle oraz jakie pełni funkcje.

Sięgając do źródeł współczesnego językoznawstwa, czyli do pracy Ferdynanda de Saussure'a znajdujemy definicję języka jako abstrakcyjnego i pozaintelektualnego systemu znaków mownych. Uczony ten dokonał także podziału na langue (język) i parole (mówienie). Langue zdefiniował jako: „część społeczną mowy, znajdującą się poza jednostką, która sama nie może języka ani stworzyć ani zmienić; istnieje on na mocy pewnego rodzaju umowy zawartej między członkami danej społeczności" (de Saussure, 1966: 30-31).

Zwrócił także uwagę na budowę języka, czyli jego strukturę, wyróżniając w niej system znaków oraz reguły ich stosowania. Istotą pojęcia „system językowy” jest to, że wszystkie elementy języka są nawzajem od siebie uzależnione oraz powiązane bezpośrednio i pośrednio. Cechą systemu językowego podkreślaną przez de Saussure’a jest jego abstrakcyjność. Przeciwstawia się ona konkretności wypowiedzi, konkretności aktów mówienia i konkretności tekstów. Opozycja langue - parole polega właśnie na abstrakcyjności langue w stosunku do konkretności parole. We wszystkich podsystemach systemu językowego jednostki mają abstrakcyjny charakter: w fonologii - fonemy, w morfologii - morfemy, w słownictwie - cechy semantyczne wyrazów, w składni - schematy i wzorce syntaktyczne. Abstrakcje lingwistyczne stanowią formę, która realizuje się w różnej substancji (ciąg dźwięków, ciąg znaków graficznych). Język jest formą, a nie substancją. Ten abstrakcyjny system językowy istnieje $\mathrm{w}$ identycznej formie $\mathrm{w}$ świadomości ludzi posługujących się danym językiem.

System językowy, oprócz zbioru znaków, tworzą również reguły łączące znaki językowe, czyli gramatyka (Kurcz, 1987: 11-12).

Polski językoznawca Tadeusz Milewski (1967: 5-8) definiuje język jako niezbędny składnik mowy. Językiem nazywa to, co w mowie jest jednocześnie społeczne, trwałe i abstrakcyjne. Mowa ludzka w swej typowej, pełnej postaci to porozumienie dźwiękowe dwóch osób, w którym jedna osoba drugą o czymś powiadamia. Mówienie jest pierwszą podstawową fazą mowy, drugą stanowi zrozumienie słów nadawcy przez odbiorcę, słuchacza. Kolejną fazą jest tekst, rozumiany jako twór konkretny, utrwalający bowiem konkretne, jedyne w swoim rodzaju rzeczywiste myśli, przeżycia i zdarzenia. Następną fazę mowy stanowi język, będący społecznym i abstrakcyjnym tworem. Jest on narzędziem, systemem wyrazów i reguł wyabstrahowanych z zapamiętanych tekstów, który umożliwia tworzenie no- 
wych tekstów. Dzięki temu, że język istnieje w bardzo podobnej formie w psychice wielu ludzi, a ponadto zawarty jest w tekstach, staje się tworem ponadindywidualnym, społecznym, stanowi ogólny system norm porozumienia, którym podporządkować się muszą wszyscy, aby uniknąć nieporozumień. Język jest zatem składnikiem mowy charakteryzującym się tym, że jest społeczny (w przeciwieństwie do indywidualnego procesu mówienia), ma trwałe istnienie w czasie (w przeciwieństwie do przemijających procesów, jakimi są mówienie i zrozumienie), jest abstrakcyjny (w przeciwieństwie do konkretnych procesów mówienia i zrozumienia oraz do konkretnego tworu, jakim jest tekst). Cztery fazy mowy nawzajem wynikają z siebie i na sobie się opierają. Abstrakcyjny system norm społecznych, jakim jest język, stanowi podstawę procesu mówienia wyrażającego myśli oraz przeżycia indywidualne i konkretne. Ponieważ jednak treści te wyrażane są w mówieniu zgodnie z normami społecznymi języka, przeto indywidualne mówienie staje się źródłem społecznego procesu zrozumienia. Utrwalony produkt zrozumienia staje się tekstem, z którego zostają wyabstrahowane normy języka, a normy te stają się podstawą nowego mówienia (Milewski, 1967: 17).

F. de Saussure wprowadził rozróżnienie między langue a parole, a Noam Chomsky w latach 60. XX wieku wyraził (pokrywające się z wcześniej wspomnianym stanowiskiem) rozróżnienie między kompetencją a realizacją (competence - performence). Chomsky twierdzi, że zdolność językową dorosłego użytkownika można częściowo opisać za pomocą czegoś, co nazwiemy sformalizowaną gramatyką tego języka. Jest to właśnie kompetencja językowa. Aby taka kompetencja uformowała się u dorosłego użytkownika języka, jako dziecko przyswajające język swojego otoczenia, musiał być wyposażony w specjalny mechanizm, który z korpusu słyszanych wypowiedzi w owym języku, był w stanie wytworzyć taką kompetencję, czyli sformalizowaną gramatykę tego języka. N. Chomsky traktuje ten mechanizm jako „wrodzone wyposażenie intelektualne, za pomocą którego dziecko daje sobie radę z nauką języka” (Chomsky, 1982: 15). Mechanizm ten został nazwany przez McNeilla urządzeniem do przyswajania języka LAD (language acquisition device). Gramatyka języka składa się z reguł: fonologicznych, syntaktycznych i semantycznych.

Analogicznie do terminu kompetencji językowej, stworzonego przez N. Chomsky’ego, Del Hymes zaproponował termin „kompetencja komunikacyjna” (za: Kurcz, 1976: 93). Według tego autora językowe zachowanie jednostki jest nie tylko sekwencją gramatycznie poprawnych zdań, ale również zbiorem wypowiedzi uwarunkowanych społecznie i sytuacyjnie. Wypowiedzi są w dużej mierze wynikiem nieuświadomionych wyborów, a reguły tych wyborów, tak jak nie zawsze uświadamiane reguły gramatyczne, posiadają dla komunikacji językowej 
charakter fundamentalny. Są na równi z gramatyką „podstawą konkretnego zachowania w mowie i dlatego powinno się je traktować jako równoważne, chociaż odrębne aspekty kompetencji” (Hymes, 1980: 46). Językowe zachowanie jednostki jest nie tylko sekwencją gramatycznie poprawnych zdań, ale również zbiorem wypowiedzi uwarunkowanych społecznie i sytuacyjnie.

Kompetencję komunikacyjną nabywa człowiek w procesie socjalizacji, pełniąc różne role społeczne w środowisku. Jest ona przypadkiem kompetencji kulturowej, wyróżnia poszczególne grupy społeczne spośród innych grup i poszczególne osoby w grupie. Zależy zatem od psychicznych predyspozycji osoby i jej stopnia uczestnictwa w życiu społecznym (Grabias, 1997: 114). Aby jednak osoba mogła dysponować kompetencją komunikacyjną, a wcześniej kompetencją językową, niezbędne są optymalne warunki, w których może się rozwijać i nabywać wspomniane kompetencje i w ten sposób stać się członkiem społeczeństwa jako wspólnoty posługującej się wspólnym kodem językowym.

\section{Teorie nabywania języka}

Jedną z pierwszych teorii podejmujących problem wyjaśniania procesu nabywania języka przez dziecko była behawiorystyczna koncepcja B. Skinnera (za: Kurcz, 1976: 59). Traktując zachowania werbalne jako rodzaj zachowań człowieka, Skinner uważał, że dziecko opanowuje reakcje werbalne tak samo, jak uczy się innych rodzajów reakcji w odpowiedzi na wzorce dorosłych. Modelem wyjaśniającym opanowywanie języka jest według behawiorystów model uczenia się instrumentalnego, a zatem dziecko przypadkowo odkrywa pewne reakcje werbalne, a wzmocnienia dorosłych sprawiają, iż stają się one stałym elementem jego zachowań.

Teoria behawiorystyczna przyniosła próbę opisania i wyjaśnienia złożonego procesu, jakim jest opanowywanie i używanie języka. B. Skinner opisał różne rodzaje zachowań werbalnych i wskazał na różne sposoby ich nabywania przez dziecko. Teoria ta ukazała różnorodność zachowań werbalnych człowieka i wskazała na znaczenie pozajęzykowych sytuacji w procesie uczenia się języka. Zaletą teorii Skinnera było zwrócenie uwagi na potrzebę analizowania zachowań werbalnych w stosunku do innych zachowań oraz pokazanie dwóch zasadniczych tendencji w opanowywaniu języka: od złożonych reakcji werbalnych ujmowanych całościowo ze względu na funkcję, do wyróżniania w tych reakcjach elementów i ustalania ich miejsca w większej wypowiedzi.

Nowe spojrzenie na opanowywanie języka przez dziecko pojawiło się pod wpływem teorii transformacyjno-generatywnej N. Chomsky’ego. Zwrócono wów- 
czas uwagę na fakt, iż dziecko nie uczy się konkretnych słów, zwrotów, czy wyrażeń drogą wytwarzania nawyków językowych, ale opanowuje abstrakcyjne reguły produkowania słów, wyrażeń i zdań. Ujęcie takie wynikało z uwzględnienia jednej z podstawowych cech języka, a mianowicie kreatywności. Chomsky twierdził, że „Ludzie posługują się językiem w sposób wysoce twórczy; stosują się do jego własnych reguł, lecz swobodnie wyrażają myśli nowe, niejednokrotnie bardzo odległe od dawniejszych doświadczeń i aktualnie odbieranych wrażeń” (Chomsky, 1977: 120).

Autor ten zaznacza, że twórczy aspekt zwykłego porozumiewania się stanowi podstawowy wyróżnik języka ludzkiego ze wszystkich znanych systemów porozumiewania się istot żywych (Chomsky, 1977: 98). Opanowywanie języka i posługiwanie się nim jest zdolnością specyficznie ludzką, zdeterminowaną prawami wynikającymi z natury umysłu człowieka. Rodzaj języka, jakiego nauczy się dziecko, zależy od tego, jakim językiem posługują się dorośli w jego otoczeniu. Z koncepcji Chomsky'ego wynika, że reguły generatywne mają uniwersalny charakter. Dziecko, słysząc wypowiedzi dorosłych, ma jedynie wykryć, jak jakiś szczegółowy rodzaj języka wyraża te uniwersalne reguły wspólne dla wszystkich języków. Dzieci mają wrodzone pojęcie zdania, a pod wpływem wypowiedzi dorosłych rozwijają szczegółowe hipotezy odpowiadające naturze tego języka, w którym formułowane są wypowiedzi (Kurcz, 1976: 35). Poparciem dla tezy N. Chomsky'ego jest koncepcja E.H. Lenneberga, który przyswajanie języka wyjaśnia w kategoriach dojrzewania biologicznego. Przytacza on następujące dowody świadczące o tym, że zachowania werbalne dziecka wyzwalane są czynnikami biologicznymi: 1) język pojawia się, zanim jego znajomość jest dziecku niezbędna; 2) przyswajanie języka nie wynika ze świadomych decyzji dziecka; 3) pojawienie się mowy nie jest spowodowane zdarzeniami zewnętrznymi; 4) przypuszczalnie istnieje „okres krytyczny” sprzyjający nabyciu danego zachowania językowego; 5) nauczanie i intensywne ćwiczenia nie wpływają na przyspieszenie tego procesu; 6) istnieje stała kolejność etapów rozwoju języka, zazwyczaj zbieżna z wiekiem (Lenneberg, 1967: 157-158). Lenneberg utrzymuje, że między sensorycznym wejściem a motorycznym wyjściem, $\mathrm{w}$ procesie uczenia się języka istotną rolę odgrywają pośredniczące funkcje poznawcze, które są odpowiedzialne za zdolność do kategoryzowania w specyficzny sposób problemów i ustalania formy uczenia. Język jest przejawem właściwości poznawczych specyficznych dla gatunku człowieka i konsekwencją cech biologicznych umożliwiających ludzki typ poznania.

Inna grupa teorii opanowywania języka przez dziecko nawiązuje do odkrywania przez nie funkcji języka. Autorem, który uważał, że opanowywanie języka należy widzieć jako rozwój funkcjonowania lub użycia języka w taki sposób, który 
wiąże każdą z funkcji ze znaczeniem, był M.A.K. Halliday (za: Kurcz, 1976: 89-92). Jego zdaniem rozwój językowy dziecka przebiega w trzech fazach. W pierwszej opanowywane są podstawowe funkcje wypowiedzi, a $\mathrm{z}$ każdą $\mathrm{z}$ nich związany jest pewien potencjał znaczeniowy. Dziecko opanowuje funkcję instrumentalną (chcę), regulacyjną (rób, co ci każę), interakcyjną, personalną, heurystyczną (powiedz mi dlaczego), imaginacyjną (wyobraźmy sobie, że) i informacyjną. Wówczas wypowiedź może pełnić tylko jedną funkcję. Poszczególne funkcje pojawiają się w kolejności ich wymieniania, a na pewno jako ostatnia opanowywana jest funkcja informacyjna. Opanowanie szczegółowych funkcji stanowi podstawę do przejścia na dojrzały system porozumiewania się.

Zdolności socjolingwistyczne dotyczą używania norm i ocen przyjętych w danej grupie społecznej oraz uczestniczenia, także językowego, w zwyczajach tej grupy. Nikt nie uczy się języka w oderwaniu od procesu komunikowania się. „Jest rzeczą oczywistą, że dziecko nie może opanować języka, jeśli nie jest poddane jego oddziaływaniu" (Lenneberg, 1967: 216). Aby takie oddziaływanie miało miejsce, dziecko musi żyć w środowisku ludzi posługujących się językiem i musi być gotowe do przyjęcia tego oddziaływania, to znaczy wolne od barier utrudniających komunikację, uniemożliwiających dziecku włączenie się do sieci interakcji komunikacyjnej.

\section{Charakterystyka rozwoju mowy dziecka}

Termin bazowych umiejętności komunikacyjnych przytaczam za M. Machoś. Cytując za autorką, „umiejętności poznawcze, które pojawiają się w pierwszym roku życia to baza, na której dziecko zbuduje system komunikacji z innymi ludźmi" (Machoś, 2018: 1). Chociaż w literaturze znajdziemy wiele publikacji dotyczących prawidłowego rozwoju dziecka, szczególnie rozwoju fizycznego, to monitorowanie rozwoju funkcji poznawczych czy językowych przez lekarzy pediatrów bądź rodziców jest często traktowane ze zbytnią pobłażliwością. W sytuacji nieprawidłowego rozwoju specjaliści pracują nad zachowaniem zaburzonym, czy uzyskaniem brakującej umiejętności na tu i teraz, czyli takiej, która powinna pojawić się u dziecka w danym wieku. Niestety, nie biorą pod uwagę prawideł rozwoju, które stanowią kontinuum etapów, w którym pierwszy implikuje pojawienie się następnego, a nie są jedynie wybiórczymi umiejętnościami pojawiającymi się w izolacji. Jak słusznie podkreśla J. Cieszyńska-Rożek, brak podstawowych umiejętności uniemożliwi dalszy rozwój funkcji poznawczych. Dziecko nie rozwija poszczególnych sprawności w oderwaniu od innych, dlatego tak ważne jest wczesne rozpoznanie i natychmiastowe rozpoczęcie stymulacji. 
Bazowe umiejętności komunikacyjne według M. Machoś to: budowanie kontaktu wzrokowego, wodzenie wzrokiem za przedmiotem, uwaga słuchowa, pole uwagi, używanie gestu wskazywania palcem, praca ręki, naśladowanie, imitacja dźwięków prymarnych, rozumienie pojęcia "taki sam”, rozumienie pojęcia „ja” (reakcja na imię), pamięć ruchowa, słuchowa i wzrokowa (Machoś, 2018: 1).

Skupienie wzroku niemowlaka na twarzy osoby dorosłej, które kształtuje się już w pierwszym miesiącu życia, jest funkcją prymarną wobec wszystkich innych funkcji wzrokowych pojawiających się w następnych miesiącach życia i będzie warunkowała dalsze uczenie się świata. Już kilka godzin po urodzeniu niemowlęta wolą patrzeć na schematyczne rysunki twarzy ludzkich niż na inne wzory percepcyjne (Tomasello, 2002). Jak wskazuje J. Cieszyńska-Rożek, jeśli dziecko nie skupia wzroku na twarzy osoby dorosłej, nie będzie mogło oglądać obrazków i uczyć się rozumienia nazw przedmiotów (Cieszyńska-Rożek, 2013). Nawiązywanie kontaktu wzrokowego ma znamiona dialogiczności, stanie się furtką umiejętności odczytywania informacji z twarzy drugiej osoby, w tym szukania potwierdzenia i aprobaty. Kontakt wzrokowy to podstawowy element mowy niewerbalnej; krótko po urodzeniu niemowlęta angażują się w protokonwersacje twarzą w twarz, które stanowią pierwsze interakcje społeczne i jak zaznacza M. Tomasello, mają jasną strukturę naprzemienną (Tomasello, 2002: 24). Taki kontakt stanowi również wymianę emocji, współodczuwania z drugim człowiekiem.

Kolejną z bazowych umiejętności komunikacyjnych jest praca ręki, w szczególności pod kontrolą wzroku. Rozwojowo dzieje się to na drodze poznania oralnego, gdy małe dziecko poznaje tak otaczający je świat i samego siebie, doświadczając tym samym mechanizmu samoregulacji. Na późniejszym etapie sprawność aparatu artykulacyjnego będzie jednym z wymiarów funkcji motorycznych wykonywanych ręką dominującą w czasie podejmowania działań manualnych. Bez wątpienia praca ręki jest skorelowana $\mathrm{z}$ gestem wskazywania palcem.

Gest wskazywania palcem jest pierwszym „zdaniem”, które dziecko kieruje do osoby dorosłej. Może mieć różne znaczenia: zobacz to, daj mi to, pokaż mi to. To świadomy proces nawiązywania rozmowy, który buduje wspólną przestrzeń dialogiczną. Gest wskazywania palcem ma jeszcze jedną bardzo ważną funkcję, ten protodialog $\mathrm{z}$ dorosłym staje się bazą kształtowania języka $\mathrm{w}$ umyśle dziecka (Cieszyńska, 2011). R. Vasta zawraca uwagę na ważne aspekty dotyczące wskazywania z użyciem gestów, tak zwane etykietowanie gestykulacyjne oraz drugie, etykietowanie z użyciem słów. „Istnieje pozytywna korelacja zachodząca pomiędzy tymi sposobami etykietowania otoczenia: dziecko, które więcej gestykuluje, będzie używało więcej nazw" (Vasta, Haith, Miller, 1995: 412). W momencie, kiedy dziecko będzie potrafiło nazywać to co pokazuje, gest zaniknie na rzecz słowa 
wypowiedzianego. Pojawienie się zdolności poznawczych, czyli użycie symboli (gest) do określenia rzeczy, związane jest z pojawieniem się zdolności językowych (nazwanie). Sugeruje to zachowanie ciągłości w rozwoju językowym, w którym gestykulacja stanowi prymitywną formę nazywania, aż do momentu pojawienia się słowa (Vasta, Haith, Miller, 1995: 412). By jednak gest się pojawil, niezbędne jest wcześniejsze pojawienie się pola wspólnej uwagi, które z kolei poprzedzone jest skupianiem wzroku na drugiej osobie.

Wspólne pole uwagi rozwija się u dziecka od 9. miesiąca życia i warunkuje kulturowe uczenie się, w szczególności naśladowanie intencjonalne (Cieszyńska-Rożek, Korendo, 2016). Budowanie z dorosłym pola uwagi, czyli świadomość wspólnego pola spostrzeżeniowego - dziecko i mama patrzą na tę samą zabawkę, dziecko przenosi wzrok z obiektu na osobę, której pokazuje ten obiekt, sprawdzając, czy ona również go widzi - będzie warunkowało rozumienie mowy i nabywanie językowych znaczeń (Tomasello, 2002). W sytuacji tej dziecko staje się inicjatorem wspólnej uwagi, podejmując interakcje społeczne (Pisula, 2012). Zaczyna w ten sposób kierować uwagą i zachowaniem dorosłego. W momencie wykorzystania gestu wskazywania palcem lub podniesienia przedmiotu, by komuś go pokazać, wchodzi w relacje komunikacyjne, czyli społeczne. Kształtowanie wspólnego pola uwagi pozwala osiągnąć relację trójstronną: dziecko - przedmiot - dorosły, a nie jak było to wcześniej - dwustronną: dziecko - przedmiot.

Naśladownictwo jest umiejętnością niezbędną w procesie uczenia się zachowań i języka, gdyż w ten sposób uczymy się wszelkich zachowań społecznych. J. Bauer pisze, że neurony lustrzane aktywują się tylko w sytuacji, gdy obserwujemy działania aktora biologicznego, rozumianego jako żywą istotę, gdyż ani sztuczna ręka, ani komputer nie są w stanie swoim działaniem aktywować układów lustrzanych u obserwatora (Bauer, 2015).

Rodzice częstokroć nie mają świadomości znaczenia umiejętności bazowych dziecka dla jego rozwoju językowego i poznawczego, jednakże spostrzegają konsekwencje ich braku. Konsekwencją najczęściej i najszybciej zauważaną są deficyty w zakresie funkcjonowania językowego: brak mowy, opóźniony bądź specyficzny rozwój mowy.

\section{Wczesne sygnały opóźnień w rozwoju językowym}

Rozwój mowy uwarunkowany jest genetycznie, ale też możliwy jedynie w kontakcie ze środowiskiem społecznym. Ogólnie mówiąc, czynniki biologiczne i społeczne są od siebie zależne (Demel, 1996: 14). 
Prawidłowa wymowa wymaga stymulacji już w czasie życia płodowego. Podstawowe narządy mowy rozwijają się między trzecim a czwartym miesiącem życia prenatalnego. Wtedy rozpoczyna się praca mięśni oddechowych, mięśni ssania, rozwój fonacyjny oraz rozwój strun głosowych. Najwcześniej wykształcony, spośród organów zmysłów, jest narząd słuchu. Wtedy też płód jest zdolny usłyszeć dźwięk bicia serca matki oraz jej głos. Dziecko rozpoznaje go, reaguje na dźwięki dochodzące $z$ otoczenia.

Niezwykłe znaczenie dla rozwoju mowy ma ukształtowanie się narządów żucia - szczęki, zębów, warg, policzków, języka. W okresie płodowym są narażone na uszkodzenia, z przyczyn genetycznych, jak i zewnętrznych (nieprawidłowe ułożenie dziecka, niedobór witamin, stres, przebyte choroby matki). W późniejszych latach życia dziecka stwierdza się też związek zaburzeń mowy z nieprawidłową budową narządów artykulacyjnych z powodu: krzywicy, próchnicy, stanów zapalnych uszu i dziąseł (Kozłowska, 1996: 10-11).

Istnieje wiele publikacji i stanowisk na temat dzieci, które mimo prawidłowo rozwiniętego słuchu oraz poziomu inteligencji nie mówią. Istnieje wiele klasyfikacji opóźnienia rozwoju mowy: alalia, afazja rozwojowa, afazja dziecięca, afazja wrodzona, niedokształcenie mowy, głuchoniemota. Precyzując pojedynczo zaburzenia, każde ze sformułowań jest inne, ale wszystkie odnoszą się do:

- zaburzeń, w których występuje brak lub/i opóźnienie rozwoju mowy;

- utraty umiejętności mówienia, już opanowanego w mniejszym lub większym stopniu, które dotyczą zatrzymania procesu rozwoju mowy (Stasiak, 2014: 345).

Należy przypomnieć klasyfikację opóźnień rozwoju mowy:

- samoistny opóźniony rozwój mowy - SORM (alalia prolongata, proste opóźnienie rozwoju mowy) może być wywołany dysharmonią rozwojową, inaczej mówiąc - zakłóceniem rozwoju mowy bez określonego czynnika etiologicznego. Nie są znane przyczyny tego zaburzenia. Podkreśla się jednak, że przy samoistnym opóźnieniu rozwoju zachowana jest zdolność rozumienia. $\mathrm{W}$ tym przypadku przyczyn opóźnienia rozwoju mowy można upatrywać w:

- indywidualnym tempie i rytmie rozwojowym. Wolniejsze tempo rozwoju dotyczy wyłącznie mówienia i prowadzi do wycinkowego opóźnienia rozwoju mowy. Ten rodzaj zakłócenia charakteryzuje się początkowym brakiem w mówieniu (do 1,6 lub 2. roku życia), a w konsekwencji jego opóźnieniem. W wieku 4-5 lat opóźnienie to samoistnie zaczyna się wyrównywać, bez specjalistycznej interwencji, a następnie przebiega prawidłowo; 
- braku dojrzałości aparatu artykulacyjnego, która prowadzi do opóźnionego dojrzewania struktur nerwowych (procesy nadawczo-odbiorcze).

Przypuszcza się, że jest to powód opóźnienia mowy czynnej. Takie dzieci: mówią mało lub wcale, przy czym ich słuch rozwija się prawidłowo, poprawnie wykonują polecenia; pojedyncze głoski artykułują poprawnie, problem występuje podczas połączenia ich w sylaby lub wyrazy; mają prawidłowo rozwinięte zdolności umysłowe, lecz występują u nich problemy w nauce czytania i pisania; nie mają problemów z mięśniami odpowiedzialnymi za artykulację; pierwsze słowa wypowiadają w wieku około 3 lat, zdania w 4. roku życia, natomiast w wieku 5-6 lat opóźnienie wyrównuje się względem rówieśników. Samoistne opóźnienie w rozwoju mowy częściej występuje u chłopców niż u dziewczynek. W większości przypadków stwierdza się u tych dzieci leworęczność;

- niesamoistny opóźniony rozwój mowy - NORM jest wynikiem zaburzeń o ustalonej przyczynie. Ma podłoże w biologicznych lub społecznych czynnikach patologicznych (uszkodzenie centralnego układu nerwowego, obwodowego narządu mowy, upośledzenie umysłowe, zaburzenia psychiczne i emocjonalne). W tym przypadku opóźnienie rozwoju mowy jest przejawem zaburzeń, a nie jedynie zakłóceń w rozwoju mowy. Brak lub opóźnienie rozwoju mowy jest pierwszym z objawów zaburzeń rozwoju psychomotorycznego, więc może być podstawą do przewidywania możliwości wystąpienia poważnych zaburzeń mowy (Jastrzębowska, Pelc-Pękala, 1999: 670-686).

\section{Wyniki badań własnych}

Refleksje przedstawione w tej części artykułu pochodzą z obszernego materiału empirycznego, zgromadzonego w czasie mojej pracy w Fundacji na rzecz Pomocy Dzieciom Niepełnosprawnym „Nowa Nadzieja” w Kaliszu. Fundacja ta powstała w 2009 roku i za cel postawiła sobie wspieranie rodzin z dziećmi niepełnosprawnymi. W trakcie pierwszych lat działania ujawnił się bardzo duży problem, z jakim zmagały się/zmagają się rodziny dzieci z całościowymi zaburzeniami rozwoju (m.in. autyzmem i Zespołem Aspergera), a mianowicie z dostępem do profesjonalnej diagnostyki i programowania terapii. W październiku 2013 roku przy Fundacji powstał Ośrodek Diagnozy i Terapii Dzieci z Zaburzeniami Rozwoju, którego objęłam kierownictwo. Głównym zadaniem Ośrodka miało być prowadzenie diagnostyki dzieci z całościowymi zaburzeniami rozwoju w ramach wielospecjalistycznego zespołu (psycholog, psychiatra, logopeda, pedagog specjalny). Bardzo 
szybko okazało się, że niemożliwe jest zawężenie działalności do diagnozowania dzieci z autyzmem czy ZA lub innymi formami całościowych zaburzeń rozwoju, gdyż oznaczałoby to selekcję prediagnostyczną. Tak więc do diagnozy były i są przyjmowane wszystkie dzieci zgłoszone przez rodziców, a proces diagnostyczny w każdym przypadku kończy się sformułowaniem rozpoznania i zaleceniami do postępowania terapeutycznego czy wspierającego. W latach 2013-2020 w Fundacji „Nowa Nadzieja” przeprowadzono 261 diagnoz. W roku 2015 uruchomiono w niej program bezpłatnych konsultacji dla rodziców zaniepokojonych rozwojem swojego dziecka. Spotkania te nie mają charakteru diagnostycznego i nie kończą się wydaniem żadnych opinii czy dokumentów, służą stwierdzeniu, czy w rozwoju dziecka rzeczywiście występują nieprawidłowości i ukierunkowaniu rodziców co do dalszego postępowania diagnostycznego lub/i terapeutycznego. W trakcie trwania programu przeprowadzono około 700 konsultacji.

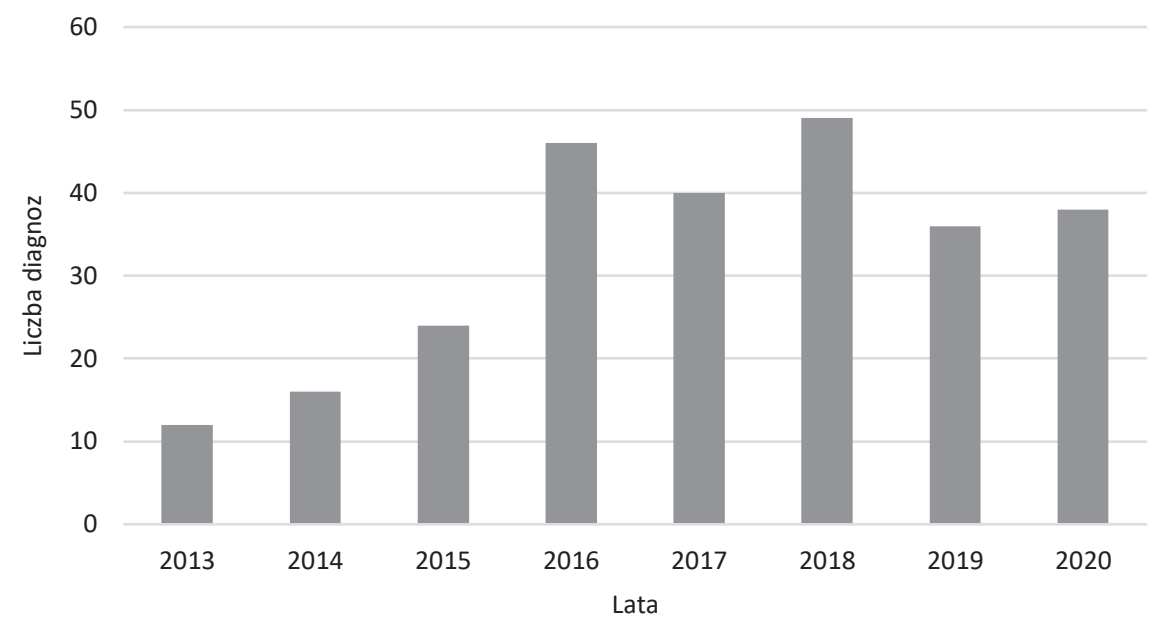

Wykres 1. Liczba diagoz w poszczególnych latach

Źródło: badania własne

Za materiał do analizy na potrzeby niniejszego artykułu posłużyły dane z przeprowadzonych diagnoz.

Przebieg procesu diagnostycznego w Fundacji „Nowa Nadzieja” ma charakter kilkuetapowy i składają się nań minimum cztery spotkania: pierwszy etap - przeprowadzenie bardzo dokładnego wywiadu z rodzicami, analiza dokumentów i/lub dostarczonych nagrań oraz obserwacja dziecka w sytuacji zabawy dowolnej; drugi etap - badanie psychologiczne i kolejna rozmowa z rodzicami; trzeci - badanie psychiatryczne; czwarty - spotkanie, podczas którego rodzice otrzymują obszerną, 
pisemną diagnozę i zalecenia odnośnie do postępowania terapeutycznego. Analizując wyniki diagnoz: 56\% rozpoznań stanowi autyzm, Zespół Aspergera lub inne postaci całościowych zaburzeń rozwoju, natomiast $44 \%$ dotyczy innych jednostek diagnostycznych.

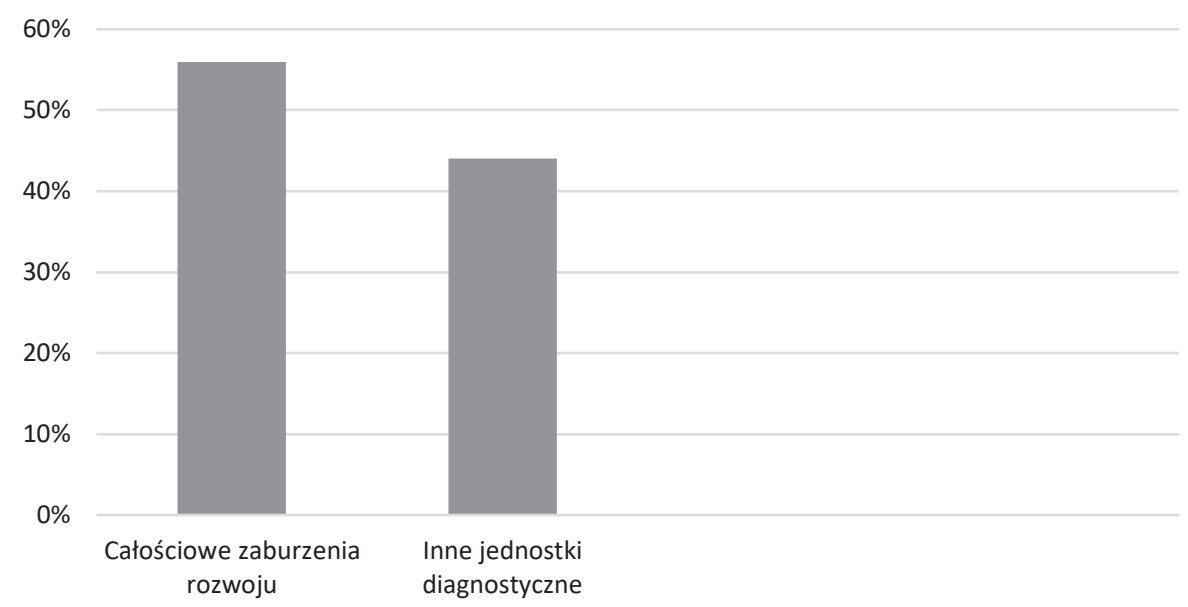

Wykres 2. Rodzaje diagnoz

Źródło: badania własne

Wśród diagnoz niebędących rozpoznaniem całościowych zaburzeń rozwoju znajdują się: niedokształcenie mowy o typie afazji, alalia, opóźniony rozwój mowy, opóźnienie rozwoju psychoruchowego o zróżnicowanej etiologii, mutyzm, zaburzenia zachowania, zachowania opozycyjno-buntownicze, zagrożenie niedostosowaniem społecznym i niedostosowanie społeczne, zaburzenia psychiczne.

Analizując powody, dla których rodzice zgłaszają się do Ośrodka wyłaniają się dwa zasadnicze: opóźniony rozwój mowy i podejrzenie innych nieprawidłowości $\mathrm{z}$ tym związanych oraz trudności w funkcjonowaniu emocjonalno-społecznym w grupie rówieśniczej lub/i w rodzinie. Rozkład tych przyczyn w odniesieniu do analizowanej grupy jest mniej więcej równomierny. Natomiast, jeżeli weźmiemy pod uwagę grupę dzieci do lat 5 (182 przypadki), to zdecydowaną przewagę wykazuje czynnik nieprawidłowości w rozwoju językowym. Oczywiście rodzice wskazują także na inne objawy w ich mniemaniu niepokojące (im starsze dziecko, tym jest ich więcej), ale tym, co najbardziej niepokoi rodziców i skłania do poszukiwania pomocy są nieprawidłowości w funkcjonowaniu językowym. Rodzice, de- 
cydując się szukać pomocy, nie znają przyczyn nieprawidłowości obserwowanych u swoich dzieci, lecz kierują się obserwowanymi rozbieżnościami między ogólnie przyjętą normą rozwojową a funkcjonowaniem własnego dziecka.

Najczęściej zgłaszane przez rodziców powody (z zakresu rozwoju językowego) podjęcia diagnostyki:

- brak mowy;

- bardzo mały zasób używanych słów;

- mowa niezrozumiała lub zrozumiała tylko dla najbliższych;

- nieumiejętność budowania zdań;

- nieumiejętność zgłaszania swoich potrzeb;

- brak reakcji na imię;

- wybiórcza reakcja na imię;

- nierozumienie poleceń;

- nierozumienie dłuższych wypowiedzi;

- brak koncentracji na dłuższych wypowiedziach, czytanych tekstach;

- mowa niefunkcjonalna (dziecko mówi, ale nie wykorzystuje wcale/w pełni swoich umiejętności w komunikacji interpersonalnej).

Standardowe pytanie, jakie pada podczas wywiadu diagnostycznego brzmi: „Kiedy Państwo zaczęliście się niepokoić rozwojem syna/córki? Kiedy powstała obawa, że coś jest nie tak?” Odpowiedzi rodziców w ogromnej większości wskazują na czas przed ukończeniem przez dziecko 2. roku życia. Oczywiście dotyczy to także rodzin zgłaszających się z dziećmi, które nie ukończyły jeszcze 2 lat.

Pogłębiony wywiad, obserwacja dziecka oraz badania psychologiczne i psychiatryczne wykazują dodatkowe nieprawidłowości w funkcjonowaniu dzieci, zwłaszcza w zakresie rozwoju poznawczego, społecznego, emocjonalnego i rozwoju zabawy, co do których można domniemywać, iż mają charakter wtórny do opóźnień w rozwoju językowym bądź z nich wynikają.

U wielu dzieci z tej grupy można obserwować brak umiejętności bazowych, o których pisałam wcześniej.

Należy zadać pytanie o przyczynę tak długiego nieraz oczekiwania na podjęcie diagnostyki, mimo mniej lub bardziej świadomego niepokoju. Tkwi ona w dość mocno ugruntowanym w świadomości społecznej stereotypie, mówiącym o bardzo indywidualnym i wymykającym się normom rozwoju językowym dzieci. Poglądy te, oparte na jednostkowych i często zniekształconych poznawczo doświadczeniach, każą wierzyć rodzicom, że „dziecko ma czas”, że niektóre dzieci „później dojrzewają do mowy" i tym podobnych. Taka postawa może doprowadzić do nieodwracalnych zaniedbań w zakresie niezbędnej terapii. Lenneberg twierdził, że w rozwoju językowym dziecka występują okresy krytyczne, co znajduje potwier- 
dzenie w praktyce terapeutycznej. Pominięcie tego okresu dla rozpoczęcia terapii może oznaczać dla dziecka trwałe opóźnienie czy ograniczenie w funkcjonowaniu językowym.

\section{Wnioski dla praktyki}

Choć symptomy zaburzeń rozwoju u dzieci mają wieloraką postać i możemy obserwować ich przeróżne postaci, to osobami, które mogą zwrócić uwagę na ich występowanie jako pierwsze są rodzice i najbliżsi z otoczenia rodziny, niebędący specjalistami i częstokroć niemający świadomości znaczenia takich zachowań, jak podzielanie uwagi czy wskazywanie palcem przez dziecko. Jednakże brak pierwszych słów, brak rozumienia, czy brak komunikacji słownej jest przez najbliższe otoczenie zauważany. Należy zatem podnosić społeczną świadomość w tym zakresie i nie bagatelizować niepokoju czy wątpliwości rodziców. Dzieci dwuletnie obowiązkowo przechodzą bilans zdrowia - warto by zwiększyć czujność wywiadu i obserwacji podczas tego badania dla oceny funkcjonowania językowego dziecka. Stwierdzenie opóźnienia w tej sferze rozwoju i pogłębiony wywiad mogą wskazać na samoistny opóźniony rozwój mowy, ale też doprowadzić do rozpoznania innych poważnych zaburzeń rozwoju, w których opóźniony rozwój mowy stanowi jeden z objawów. W takich przypadkach wczesne rozpoczęcie terapii jest bezcenne i daje dziecku szanse na odwrócenie niekorzystnego scenariusza rozwoju.

\section{Bibliografia}

Bauer J. (2015), Empatia. Co potrafia lustrzane neurony?, Warszawa.

Chomsky N. (1977), Lingwistyka a filozofia: współczesny spór o filozoficzne założenia teorii języka, Warszawa.

Chomsky N. (1982), Zagadnienia teorii składni, Wrocław.

Cieszyńska J. (2011), Wczesna diagnoza i terapia zaburzeń autystycznych. Metoda Krakowska, Kraków.

Cieszyńska-Rożek J. (2013), Metoda Krakowska wobec zaburzeń rozwoju dzieci, Kraków.

Cieszyńska-Rożek J., Korendo M. (2016), Wczesna interwencja terapeutyczna w ujęciu metody krakowskiej, [w:] K. Kaczorowska-Bray, S. Milewski (red.), Wczesna interwencja logopedyczna, Gdańsk, s. 380-412

Demel G. (1996), Minimum logopedyczne nauczyciela przedszkola, Warszawa.

Grabias S. (1997), Język w zachowaniach społecznych, Lublin.

Hymes D. (1980), Socjolingwistyka i etnografia mówienia, [w:] M. Głowiński (red.), Język i społeczeństwo, Warszawa, s. 41-82 
Jastrzębowska G., Pelc-Pękala O. (1999), Diagnoza i terapia opóźnionego rozwoju mowy, [w:] T. Gałkowski, G. Jastrzębowska (red.), Logopedia. Pytania i odpowiedzi. Podręcznik akademicki, Opole, s. $346-362$

Kozłowska K. (1996), Pomagamy dzieciom z zaburzeniami mowy. Podręczny poradnik logopedyczny, Kielce.

Kurcz I. (1976), Psycholingwistyka: przegląd problemów badawczych, Warszawa.

Kurcz I. (1987), Język a reprezentacja świata w umyśle, Warszawa.

Lenneberg E. (1967), Biological Foundations of Language, New York.

Machoś M. (2018), Diagnoza bazowych umiejętności komunikacyjnych. Karty obserwacji, Bytom.

Milewski T. (1967), Językoznawstwo, Warszawa.

Pisula E. (2012), Autyzm. Od badań mózgu do praktyki psychologicznej, Sopot.

Saussure F. (1966), Course in General Linguistics, New York.

Stasiak J. (2014), Alalia. Perspektywy opisu, [w:] S. Grabias, M. Kurkowski (red.), Logopedia. Teoria zaburzeń mowy, Lublin, s. 337-358.

Tomasello M. (2002), Kulturowe źródła ludzkiego poznawania, Warszawa.

Vasta R., Haith M., Miller S.A. (1995), Psychologia dziecka, Warszawa. 
